\title{
SIMULASI PERUBAHAN KUAT TEKAN BETON PADA KONDISI EKSTRIM PASCA PEMBAKARAN
}

\author{
Alim Alkhamuddin ${ }^{1}$, Adiguna $^{2^{*}}$ \\ ${ }^{12}$ Prodi Teknik Sipil Fakultas Teknik Universitas PGRI Palembang \\ *Corresponding Author, Email : adigunaym@gmail.com
}

\begin{abstract}
ABSTRAK
Perubahan kuat tekan beton setelah pembakaran dan pendinginan dengan penyiraman dapat digunakan untuk memperkirakan tingkat keruntuhan bangunan yang terbakar dan didinginkan dengan menggunakan air. Metode yang digunakan dalam penelitian ini adalah metode eksperimen yang mensyaratkan beton K300 yang dibentuk dengan ukuran $15 \mathrm{~cm} \times 15 \mathrm{~cm} \times 15 \mathrm{~cm}$ sebanyak 21 buah dengan variasi yaitu 3 beton normal, pembakaran beton 1 jam, 2 jam dan 3 jam dengan kesamaan pendinginan di setiap 3 beton. Selain itu, pembakaran beton dilakukan pada 1 jam, 2 jam dan 3 jam dengan pendinginan yang menggunakan penyiraman pada setiap 3 beton. Pengumpulan data dilakukan dengan menggunakan teknik pengujian terhadap objek percobaan dan bahan penyusun objek percobaan dengan aturan yang digunakan di laboratorium yang mengacu pada SNI. Hasil objek percobaan menunjukkan bahwa beton yang dibakar dilakukan pendinginan secara biasa penurunan kuat tekan betonnya sebesar 8\% pada 1 jam pembakaran, $13 \%$ pada 2 jam pembakaran dan 32\% pada 3 jam pembakaran dari beton normal. Kemudian pada pembakaran dan pendinginan dengan menggunakan penyiraman, persentase penurunan kuat tekan beton sebesar $20 \%$ pada 1 jam pembakaran, $32 \%$ pada 2 jam pembakaran dan $40 \%$ pada 3 jam pembakaran. Dari hasil pengujian dapat disimpulkan bahwa proses pendinginan dengan penyiraman pada pembakaran menyebabkan bertambahnya penurunan kekuatan beton itu sendiri.
\end{abstract}

Kata Kunci : beton, pembakaran, pendinginan, Kekuatan tekanan

\section{PENDAHULUAN}

Dalam dunia konstruksi bangunan saat ini, beton adalah salah satu bahan yang sangat sering digunakan dalam mendirikan suatu bangunan. Hal tersebut dikarenakan beton merupakan material yang relatif murah dan mudah dalam pelaksanaan konstruksinya. Material beton relatif lebih tahan terhadap temperatur tinggi akibat kebakaran dibandingkan struktur baja ataupun kayu yang tidak diproteksi secara khusus. Salah satu kelebihan struktur beton terlihat pada saat mengalami kebakaran adalah keruntuhannya tidak terjadi secara tiba-tiba. Kenyataan dilapangan, sering kali kita jumpai pemadaman kebakaran pada bangunan gedung yang terbakar menggunakan air yang disemprotkan dari mobil pemadam kebakaran. Bangunan yang terbuat dari beton tersebut mengalami perubahan suhu yang ekstrim dari kondisi terbakar dalam suhu yang tinggi, tiba-tiba mengalami penurunan suhu dalam waktu singkat dengan adanya perlakuan penyiraman air oleh petugas pemadam kebakaran.

Penelitian ini dilakukan pada skala laboratorium dengan mensimulasikan kondisi bangunan konstruksi beton yang terbakar melalui media kubus yang dibakar pada suhu tertentu kemudian langsung disiram dengan air sehingga mengalami penurunan suhu yang ekstrim. Penelitian ini diharapkan mampu memberikan gambaran seberapa parah kerusakan struktur beton akibat terjadinya kebakaran yang kemudian dipadamkan menggunakan air. 


\section{TINJAUAN PUSTAKA}

Dalam konstruksi, beton adalah sebuah bahan bangunan (material) komposit yang terbuat dari kombinasi aggregat dan pengikat semen. Beton ini didapatkan dengan cara mencampur agregat halus (pasir), agregat kasar (kerikil), atau jenis agregat lain dan air, dengan semen portland atau semen hidrolik yang lain, kadang kadang dengan bahan tambahan (additif) yang bersifat kimiawi ataupun fisikal pada perbandingan tertentu, sampai menjadi satu kesatuan yang homogen. Campuran tersebut akan mengeras seperti batuan. Pengerasan terjadi karena peristiwa reaksi kimia antara semen dengan air.

Seiring dengan penambahan umur, beton akan semakin mengeras, dan akan mencapai kekuatan rencana ( f'c ) pada usia 28 hari. Kecepatan bertambahnya kekuatan beton ini sangat dipengaruhi oleh faktor air semen dan suhu selama perawatan. Kekuatan tekan merupakan salah satu kinerja utama beton. Kekuatan tekan adalah kemampuan beton untuk menerima gaya tekan per satuan luas.

\section{Bahan Penyusun Beton}

Untuk memahami dan mempelajari seluruh perilaku elemen gabungan diperlukan pengetahuan tentang karakteristik masing-masing komponen. Beton dihasilkan dari sekumpulan interaksi mekanis dan kimiawi sejumlah material pembentuknya. Bahan pembentuk beton terdiri dari campuran agregat halus dan kasar dengan semen dan air sebagai pengikatnya.

\section{Agregat}

Agregat adalah bahan-bahan campuran beton yang saling diikat oleh perekat semen. Agregat ini harus bergradasi sedemikian rupa sehingga seluruh massa beton dapat berfungsi sebagai benda yang utuh, homogen, dan rapat, dimana agregat yang berukuan kecil befungsi sebagai pengisi celah yang ada diantara agregat berukuran besar.

Dua jenis agregat adalah :

a. Agregat kasar ( kerikil, batu pecah )

Agregat kasar adalah agregat dengan besar butir lebih dari $5 \mathrm{~mm}$. ( PBBI 1971, NI-2 ).

Syarat-syarat agregat kasar :

1. Harus terdiri dari butir-butir yang keras dan tidak berpori

2. Butir-butir agregat kasar harus bersifat kekal, artinya tidak pecah atau hancur oleh pengaruh-pengaruh cuaca, seperti terik matahari dan hujan.

3. Agregat kasar tidak boleh mengandung zat-zat yang dapat merusak beton, seperti zat-zat yang reaktif alkali.

4. Agregat kasar tidak boleh mengandung Lumpur lebih dari $1 \%$. Apabila kadar Lumpur melampaui $1 \%$ maka agregat kasar harus dicuci.

b. Agregat halus ( pasir )

Agregat yang berupa pasir sebagai hasil desintegrasi alami dari batu-batuan atau berupa pasir buatan yang dihasilkan oleh alat-alat pemecah batu (PBBI 1971, N.I.-2). 
Syarat agregat halus :

1. Agregat halus terdiri dari butir-butir yang tajam dan keras.

2. Butir agregat halus harus bersifat kekal, artinya tidak pecah atau hancur oleh pengaruh cuaca seperti terik matahari dan hujan.

3. Kandungan lumpur tidak boleh lebih dari 5\% (ditentukan terhadap berat kering). Yang diartikan dengan lumpur adalah bagian-bagian yang dapat melalui ayakan 0,063 mm. Apabila kadar lumpur lebih dari 5\%, maka agregat harus dicuci.

4. Pasir laut tidak boleh dipakai sebagai agregat halus untuk semua mutu beton, kecuali dengan petunjuk dari lembaga pemeriksaan bahan yang diakui

\section{Semen}

Semen Portland adalah semen hidrolis yang dihasilkan secara menghaluskan klinker yang terutama terdiri dari silikat-silikat kalsium yang bersifat hidrolis ditambah dengan bahan yang mengatur waktu ikat (umumnya gips). Semen berfungsi merekatkan butirbutir agregat agar membentuk suatu massa padat dan juga untuk mengisi rongga udara diantara butir agregat. Semen merupakan bahan ikat yang penting dan banyak digunakan dalam pembangunan fisik di sektor konstruksi sipil. Jika semen ditambah air akan menjadi pasta semen. Jika pasta semen ditambah agregat halus akan menjadi mortar dan jika semen ditambah air ditambah agregat halus dan agregat kasar akan menjadi campuran beton segar yang setelah mengeras akan menjadi beton keras ( concrete).

\section{Air}

Air digunakan sebagai bahan pencampur dan pengaduk beton untuk mempermudah pekerjaan. Menurut PBBI 1971 N.I.- 2, pemakaian air untuk beton tersebut sebaiknya memenuhi persyaratan sebagai berikut :

1. Air harus bersih

2. Tidak mengandung lumpur

3. Tidak mengandung garam-garam yang dapat merusak beton seperti asam, zat organik

4. Tidak mengandung minyak dan alkali.

5. Tidak mengandung senyawa asam.

\section{Sifat Beton Pasca Bakar}

Menurut Sumardi (2000) kebakaran pada hakekatnya merupakan reaksi kimia dari combustible material dengan oksigen yang dikenal dengan reaksi pembakaran yang menghasilkan panas. Panas hasil pembakaran ini diteruskan ke massa beton/mortar dengan dua macam mekanisme yakni pertama secara radiasi yaitu pancaran panas diterima oleh permukaan beton sehingga permukaan beton menjadi panas. Pancaran panas akan sangat potensial, jika suhu sumber panas relatif tinggi. Kedua secara konveksi yaitu udara panas yang bertiup/bersinggungan dengan permukaan beton/mortar sehingga beton menjadi panas. Bila tiupan angin semakin kencang, maka panas yang dipindahkan dengan cara konveksi semakin banyak. Tjokrodimuljo (2000) mengatakan bahwa beton pada dasarnya tidak diharapkan mampu menahan panas sampai di atas $250^{\circ} \mathrm{C}$. Akibat panas, beton akan mengalami retak, terkelupas (spalling), dan kehilangan kekuatan. Kehilangan kekuatan 
terjadi karena perubahan komposisi kimia secara bertahap pada pasta semennya. Selain hal tersebut di atas, panas juga menyebabkan beton berubah warna. Bila beton dipanasi sampai suhu sedikit di atas $300^{\circ} \mathrm{C}$, beton akan berubah warna menjadi merah muda. Jika di atas $600^{\circ} \mathrm{C}$, akan menjadi abu-abu agak hijau dan jika sampai di atas $900^{\circ} \mathrm{C}$ menjadi abuabu. Namun jika sampai di atas $1200^{\circ} \mathrm{C}$ akan berubah menjadi kuning. Dengan demikian, secara kasar dapat diperkirakan berapa suhu tertinggi selama kebakaran berlangsung berdasarkan warna permukaan beton pada pemeriksaan pertama. Selanjutnya, Ahmad (2001) membahas kelayakan balok beton bertulang pascabakar secara analisis dan eksperimen. Penelitian dilakukan terhadap lima benda uji berbentuk balok beton bertulang. Empat balok dibakar di dalam tungku pada temperatur $200^{\circ} \mathrm{C}$ dan $400^{\circ} \mathrm{C}$ selama \pm 3 jam dan satu balok lain yang tidak dibakar sebagai pembanding. Hubungan tegangan regangan memperlihatkan perubahan kemiringan kurva atau dengan kata lain terjadi penurunan kekakuan sejalan dengan kenaikan temperatur dan diikuti dengan penambahan regangan maksimum.

\section{Kuat Tekan Beton}

Dalam SK SNI M - 14-1989 - E dijelaskan pengertian kuat tekan beton yakni besarnya beban per satuan luas yang menyebabkan benda uji beton hancur bila dibebani gaya tekan tertentu, yang dihasilkan oleh mesin tekan. Selanjutnya Mulyono (2006) mengemukakan bahwa kuat tekan beton mengidentifikasikan mutu sebuah struktur di mana semakin tinggi tingkat kekuatan struktur yang dikehendaki, maka semakin tinggi pula mutu beton yang dihasilkan.

Adapun faktor lain yang dapat mempengaruhi mutu kekuatan beton seperti yang dikemukakan oleh Mulyono (2006) yaitu:

1. Proporsi bahan penyusun,

2. Metode pencampuran,

3. Perawatan,

4. Keadaan pada saat pengecoran.

Sifat-sifat dan karaktristik material penyusun beton akan mempengaruhi kinerja beton yang dibuat. Kinerja beton ini harus disesuaikan dengan kelas dan mutu beton yang dikerjakan, sehingga dalam penggunaannya dapat disesuaikan dengan bangunan ataupun konstruksi yang akan dibangun untuk mendapatkan hasil yang memuaskan dan sesuai kebutuhan.

Menurut PBI’ 1971 beton dibagi dalam kelas dan mutu sebagai berikut :

Tabel 1. Kelas dan Mutu Beton

\begin{tabular}{|c|c|c|c|}
\hline $\begin{array}{c}\text { Kelas } \\
\text { Beton }\end{array}$ & $\begin{array}{c}\text { Mutu } \\
\text { Beton }\end{array}$ & $\begin{array}{c}\text { Kekuatan Tekan } \\
\text { Maksimum }\left(\mathrm{Kg} f / \mathrm{cm}^{2}\right)\end{array}$ & Tujuan Pemakaian Beton \\
\hline I & Bo & $50-80$ & Non-Struktural \\
\hline \multirow{3}{*}{ II } & $B 1$ & 100 & Rumah Tinggal \\
& $K 125$ & 125 & Perumahan \\
& $K 175$ & 175 & Perumahan \\
\hline \multirow{3}{*}{ III } & $K 225$ & 225 & Jembatan, Bangunan tinggi, \\
& $>$ K225 & $>225$ & Terowongan kereta api \\
\hline
\end{tabular}




\section{METODE PENELITIAN}

Penelitian ini dilakukan di Laboratorium Dinas PU Bina Marga Propinsi Sumatera Selatan. Benda uji adalah beton K300 umur 28 hari berbentuk kubus dengan ukuran $15 \mathrm{~cm}$ x $15 \mathrm{~cm}$ x $15 \mathrm{~cm}$. benda uji berjumlah 21 buah dengan variasi beton normal, beton dibakar 1 jam, 2 jam dan 3 jam dengan pendinginan biasa, dan beton dibakar 1 jam, 2 jam, dan 3 jam dengan penyiraman air. Kemudian tiap variasinya dibuat masing-masing 3 buah.

Kemudian seluruh benda uji dimasukan kedalam mesin uji kuat tekan, dan diuji kuat tekannya.

\section{HASIL DAN PEMBAHASAN}

Beton yang sudah dibakar baik dengan pendinginan biasa maupun dengan penyiraman air mengalami penurunan kuat tekan, perhitungan persentase kuat tekan beton dari seluruh variasi dapat dihitung dengan rumus berikut :

1. Beton dibakar 1 jam

$$
\Delta \sigma=\frac{\sigma \mathrm{BN}-\sigma \mathrm{BB}}{\sigma \mathrm{BN}} \times 100=\frac{401,01-367,12}{401,01} \times 100 \%=8 \%
$$

2. Beton dibakar 2 jam

$$
\Delta \sigma=\frac{\sigma \mathrm{BN}-\sigma \mathrm{BB}}{\sigma \mathrm{BN}} \times 100=\frac{401,01-348,34}{401,01} \times 100 \%=13 \%
$$

3. Beton dibakar 3 jam

$$
\Delta \sigma=\frac{\sigma \mathrm{BN}-\sigma \mathrm{BB}}{\sigma \mathrm{BN}} \times 100=\frac{401,01-271,52}{401,01} \times 100 \%=32 \%
$$

4. Beton dibakar 1 jam dengan penyiraman air

$$
\Delta \sigma=\frac{\sigma \mathrm{BN}-\sigma \mathrm{BB}}{\sigma \mathrm{BN}} \times 100 \frac{401,01-320,90}{401,01} \times 100 \%=20 \%
$$

5. Beton dibakar 2 jam dengan penyiraman air

$$
\Delta \sigma=\frac{\sigma \mathrm{BN}-\sigma \mathrm{BB}}{\sigma \mathrm{BN}} \times 100=\frac{401,01-274,36}{401,01} \times 100 \%=32 \%
$$

6. Beton dibakar 3 jam dengan penyiraman air

$$
\Delta \sigma=\frac{\sigma \mathrm{BN}-\sigma \mathrm{BB}}{\sigma \mathrm{BN}} \times 100=\frac{401,01-242,10}{401,01} \times 100 \%=40 \%
$$

Tabel 2. Perbandingan Kuat Tekan Beton Dari Seluruh Variasi

\begin{tabular}{|c|c|c|c|c|c|}
\hline \multirow{2}{*}{$\begin{array}{c}\text { Variasi Waktu } \\
\text { Pembakaran }\end{array}$} & \multicolumn{4}{|c|}{ Veton } & \multicolumn{2}{|c|}{$\begin{array}{c}\text { Dibakar dengan } \\
\text { Pormal }\end{array}$} & \multicolumn{2}{c|}{$\begin{array}{c}\text { Dibakar dengan } \\
\text { Pendinginan Biasa }\end{array}$} & \multicolumn{2}{c|}{ Penyiraman Air } \\
\cline { 2 - 6 } & $(\sigma \mathrm{bk})$ & $(\sigma \mathrm{bk})$ & Penurunan & $(\sigma \mathrm{bk})$ & Penurunan \\
\hline & \multirow{3}{*}{401,01} & 367,12 & $8 \%$ & 320,90 & $20 \%$ \\
\cline { 4 - 6 } & & 348,34 & $13 \%$ & 274,36 & $32 \%$ \\
\cline { 4 - 6 } & 271,52 & $32 \%$ & 242,10 & $40 \%$ \\
\hline 2 jam & & & & \\
\hline
\end{tabular}




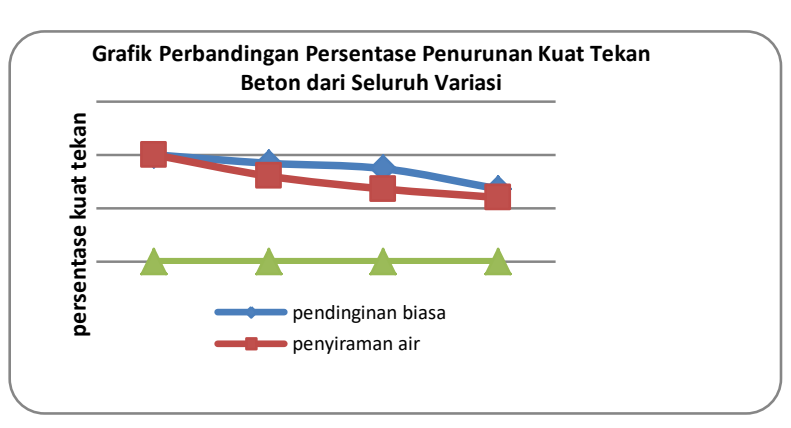

Gambar 1. Perbandingan Persentase Penurunan Kuat Tekan Beton

Penurunan kuat tekan pada beton sudah pasti terjadi setelah beton tersebut dibakar, tetapi proses pendinginan yang berbeda dapat memberikan penurunan kuat tekaan beton yang berbeda pula. Pada penelitian ini didapatkan hasil pengujian kuat tekan beton yang berbeda pada beton yang dibakar dan didinginkan dengan cara didiamkan saja pada suhu ruang dan beton yang dibakar dan didinginkan dengan penyiraman air. Pada beton yang ddinginkan dengan cara biasa untuk pembakaran 1 jam, 2 jam dan 3 jam persentase penurunan kuat tekan betonnya adalah $8 \%, 15 \%$ dan $31 \%$. Kemudian untuk beton yang didinginkan dengan penyiraman air persentase penurunan kuat tekan beton untuk waktu pembakaran 1 jam, 2 jam dan 3 jam mecapai 19\%, 32\% dan 42\%. Dari hasil penelitian ini dapat dilihat bahwa penyiraman pada beton yang dibakar dapat menambah penurunan kekuatan beton itu sendiri. Kemudian menurut PBI 1971 Bab 4 pasal 8 ayat 1 beton yang mengalami penurunan kekuatan hingga $20 \%$ lebih tidak dapat dipergunakan kembali, jadi dari peraturan tersebut dapat ditarik kesimpulan yaitu beton dengan pembakaran 1 jam, 2 jam dengan pendinginan biasa dan beton dengan pembakaran 1 jam dengan penyiraman air masih dapat dipergunakan lagi karena penurunan kekuatannya kurang dari $20 \%$, selebihnya tidak dapat dipergunakan kembali karena penurunan kuat tekannya lebih dari $20 \%$.

\section{KESIMPULAN}

Dari hasil penelitian ini dapat ditarik beberapa kesimpulan sebagai berikut :

1. Beton normal K300 yang dibakar selama lebih dari satu jam kuat tekan beton tersebut akan mengalami penurunan minimal $8 \%$.

2. Semakin lama proses pembakaran pada beton maka akan semakin besar pula penurunan kuat beton, bahkan untuk beberapa variasi pembakaran penurunan kuat tekan beton bisa mencapai dua kali lipat setiap jamnya.

3. Pendinginan beton setelah dibakar dengan penyiraman air akan berdampak semakin besar penurunan kekuatan beton pada pembakaran selama 3 jam penurunan kekuatan beton mencapai $40 \%$.

Mengacu pada PBI 1971 Bab 4 pasal 8 ayat 1 yaitu kuat tekan beton yang sudah mengalami penurunan hingga kekuatan sisa dibawah $80 \%$ dari kekuatan beton rencana tidak dapat diperguankan lagi, maka dari hasil penelitian ini ada tiga variasi yang tidak dapat dipergunakan kembali yaitu beton bakar 3 jam dengan pendinginan biasa, beton bakar 2 jam dan 3 jam denagn penyiraman air. 


\section{DAFTAR PUSTAKA}

Aji, Pujo, Ir, MT, Dr.techn dan Purwono, Rachmat Ir, MSc, Prof. IP-U HAKI, 2010. "Pengendalian Mutu Beton sesuai SNI, ACI, dan ASTM", Penerbit ITSPress, Surabaya.

Anggraini, Retno. 2008. “Porositas Beton Mutu Tinggi Pasca Bakar”. Jurusan Teknik Sipil Universitas Brawijaya.

Departemen Pekerjaan Umum dan Tenaga Listrik.1971. "Peraturan Beton Bertulang Indonesia”. LPMB. Bandung

Mulyono, Tri. 2004. “Teknologi beton”. Penerbit Andi Offset. Yogyakarta.

Nawy, E. G.; Tavio; dan Kusuma, B. 2010. "Beton Bertulang : Sebuah Pendekatan Mendasar, Edisi kelima edisi tata cara ACI 318-05”, Penerbit ITSPress, Surabaya

Ray, Noman. 2002. "Pengaruh WC Ratio Pada Perubahan Perilaku Beton Mutu Normal Pada Temperatur Tinggi Pasca Kebakaran”. Jurusan Teknik Sipil. ITATS

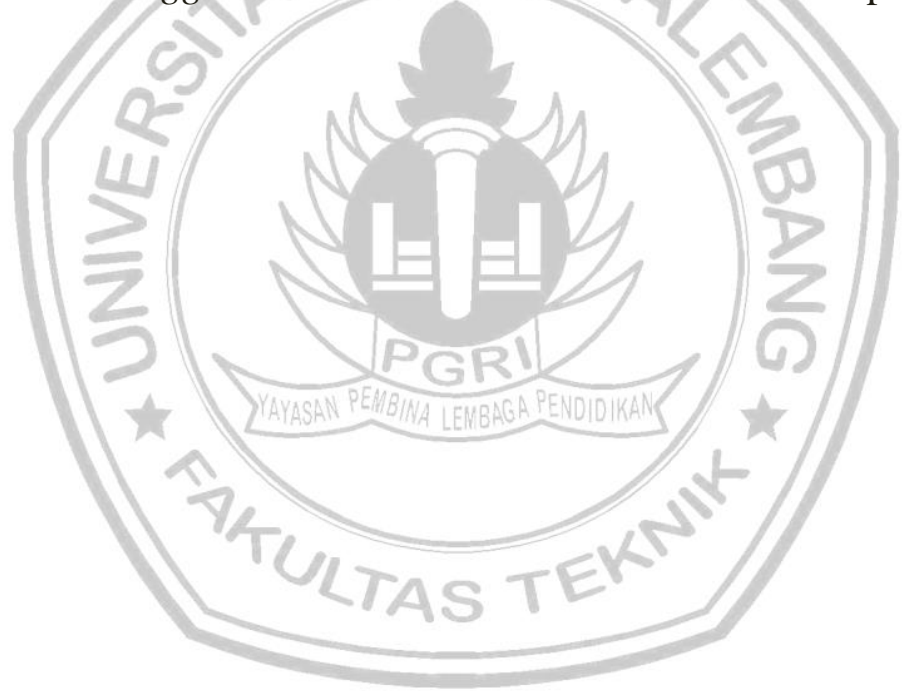

